\title{
MENINGKATKAN PRESTASI BELAJAR SEJARAH MELALUI PENERAPAN METODE TUTOR SEBAYA PADA SISWA SMK NEGERI I BAURENO KABUPATEN BOJONEGORO
}

\author{
Siti Nur Azizah \\ Sitinurazizah222@gmail.com \\ SMK Negeri I Baureno Bojonegoro
}

\begin{abstract}
Abstrak
Proses belajar mengajar harus mampu menciptakan suasana kondusif yang membebaskan siswa dari segala perasaan takut, malu, terpaksa, dan berbagai hal yang dapat menghambat tumbuh dan berkembangnya kreativitas siswa. Salah satunya dengan menggunakan model pembelajaran kooperatif dengan teknik tutor sebaya. Penelitian bertujuan mengetahui pengaruh penerapan metode tutor sebaya untuk meningkatkan prestasi siswa pada mata pelajaran Sejarah Indonesia (SI) materi Sejarah dalam konsep ruang dan waktu pada siswa Kelas X TKRO-1 SMKN 1 Baureno Kabupaten Bojonegoro. Penelitian ini merupakan penelitian tindakan kelas yang dilakukan untuk meningkatkan kemampuan siswa dalam meningkatkan prestasi siswa di kelas. Pendekatan yang digunakan dalam penelitian ini adalah pendekatan kuantitatif. Hasil penelitian menunjukkan nilai rata-rata kelas meningkat setiap siklus, yaitu: siklus I 69,12 (44,12\%), siklus II $78,53(85,29 \%)$. Sehingga penerapan metode tutor sebaya dapat meningkatkan prestasi mata pelajaran SI materi Sejarah dalam konsep ruang dan waktu pada siswa Kelas X TKRO-1 SMK Negeri 1 Baureno Kabupaten Bojonegoro.
\end{abstract}

Kata Kunci: Tutor Sebaya, prestasi siswa

\section{PENDAHULUAN}

Dalam keseluruhan proses pendidikan, kegiatan belajar mengajar adalah proses pokok yang harus dilalui oleh seorang pendidik atau guru. Berhasil tidaknya suatu tujuan pendidikan bergantung kepada bagaimana proses belajar mengajar dirancang dan disajikan.

Tenaga kependidikan merupakan suatu komponen yang penting dalam penyelenggaraan pendidikan, yang bertugas menyelenggarakan kegiatan mengajar, melatih, mengembangkan, mengelola dan memberikan pelayanan teknis dalam bidang pendidikan. Salah satu unsur tenaga kependidikan adalah tenaga pengajar yang tugas utamanya adalah mengajar. Karena tugasnya mengajar, maka dia harus mempunyai wewenang mengajar berdasarkan kualifikasi sebagai tenga pengajar/guru.

Pada mata pelajaran Sejarah yang sebagian besar materinya berisi deskriptif, biasanya metode yang digunakan oleh guru adalah metode ceramah. Guru dalam melaksanakan pembelajaran Sejarah ini menularkan pengetahuan dan informasi dalam menggunakan lisan. Dari hal ini dapat dilihat bahwa keaktifan siswa kurang berperan, sehingga untuk berpikir kreatif pun siswa mengalami hambatan, selain itu metode ceramah ini menimbulkan rasa bosan pada siswa, sehingga metode ini dirasa kurang efektif. Oleh karena itu dalam proses belajar mengajar perlu adanya pendekatan pembelajaran yang lebih efektif mampu menciptakan suasana lebih mengaktifkan siswa, khususnya pada mata pelajaran Sejarah.

Hisyam Zaini dalam Amin Suyitno (2004:24) menyatakan bahwa “" Metode belajar yang paling baik adalah dengan mengajarkan kepada orang lain. Oleh karena itu, pemilihan model pembelajaran tutor sebaya sebagai strategi pembelajaran akan sangat membantu siswa di dalam mengajarkan materi kepada teman-temannya". Metode berasal dari dua kata yaitu meta dan hodos. Meta artinya melalui dan hodos artinya jalan atau cara, dnegan demikian definisi metode adalah suatu jalan atau carra yang harus dilalui 
untuk mencapai suatu tujuan (Abudin Nata, 2007.31). Sumber yang lain yang menyebutkan bahwa metode berasal dari kata bahasa Jerman methodica artinya ajaran tentang metode. Dalam bahasa Yunani metode berasal dari kata methodos yang artinya jalan yang dalam bahasa Arab disebut thariq (Hasanuddin, 2006,35).

Dari pengertian tersebut dapat dijabarkan bahwa metode merupakan suatu cara atau jalan yang digunakan untuk mencapai suatu tujuan. Adapun manfaat dari penggunaan metode dalam proses belajar mengajar adalah sebagai alat untuk mempermudah seorang guru dalam menyampaikan materi pelajaran. Hal ini bertujuan untuk memudahkan siswa dalam menyerap materi yang disampaikan oleh guru selain itu juga dapat berfungsi sebagai suatu alat evaluasi pembelajaran.

\section{Metode Pembelajaran Tutor Sebaya}

Tutor sebaya adalah seorang teman atau beberapa orang siswa yang ditunjuk oleh guru (sesuai kriteria menjadi tutor sebaya) dan ditugaskan untuk membantu siswa yang mengalami kesulitan belajar. Pengajaran dengan tutor sebaya adalah kegiatan belajar siswa dengan memanfaatkan teman sekelas yang mempunyai kemampuan lebih untuk membantu temannya dalam melaksanakan suatu kegiatan atau memahami suatu konsep (Winataputra, Udin S,2009,14).

Menurut etimologi tutor adalah guru pribadi, mengajar ekstra atau memberi les/ pengajaran. Pendidik adalah tenaga kependidikan yang berkualifikasi sebagai guru, dosen, konselor, pamong belajar, widyaiswara, tutor, instruktur, fasilitator dan sebutan lain yang sesuai dengan kekhususannya, serta berpartisipasi dalam menyelenggarakan pendidikan (Yamin, Martinis, 2004,10). Dimana tutor merupakan sebutan bagi orang yang mengajar dalam pendidikan non-formal, walaupun yang menjadi tutor adalah seorang guru dalam pendidikan formal.

\section{Prestasi Belajar}

Prestasi belajar adalah sebuah kalimat yang terdiri dari dua kata, yakni "prestasi" dan "belajar". antara kata "prestasi" dan "belajar" mempunyai arti yang berbeda. "prestasi" adalah hasil dari suatu kegiatan yang telah dikerjakan, diciptakan baik secara individu maupun kelompok. Prestasi tidak akan pernah dihasilkan selama seseorang tidak melakukan kegiatan. "belajar" adalah suatu aktivitas yang dilakukan secara sadar untuk mendapatkan sejumlah kesan dari bahan yang telah dipelajari. Menurut kamus bahasa Indonesia "belajar" adalah berusaha (dan sebagainya) supaya mendapatkan suatu kepandaian. Belajar adalah suatu aktivitas yang sadar akan tujuan. Tujuan dalam belajar adalah terjadinya perubahan dalam diri individu. Perubahan dalam arti menuju perkembangan pribadi individu seutuhnya.

\section{Pembelajaran Sejarah dengan Teknik Tutor Sebaya}

Dalam pembelajaran Sejarah sebenarnya telah banyak upaya yang dilakukan oleh guru kelas untuk meningkatkan prestasi belajar siswa. Namun usaha itu belum menunjukkan hasil yang optimal. Rentang nilai siswa yang pandai dengan siswa yang kurang pandai terlalu mencolok. Untuk itu perlu diupayakan pula agar rentang nilai siswa tersebut tidak terlalu jauh yaitu dengan memanfaatkan siswa yang pandai untuk menularkan kemampuannya pada siswa lain yang kemampuannya lebih rendah. Tentu saja guru yang menjadi perancang model pembelajaran harus mengubah bentuk pembelajaran yang lain.

Sekilas jika dilihat banyak sekali permasalahan yang dialami siswa. Misalnya, siswa mengantuk saat pelajaran, hal ini dikarenakan banyaknya kegiatan di pondok pesantren, siswa harus mengikuti sekolah diniyah di pagi hari dan sekolah umum di siang hari. Kita ketahui sendiri bahwa siang hari sebenarnya bukan waktu 
yang tepat untuk menerima pelajaran, karena konsentrasi siswa sudah berkurang di waktu siang hari. Selain mengantuk saat menerima pelajaran, siswa juga mempunyai prestasi hasil belajar yang kurang, jika dilihat dari daftar nilai yang dihasilkan. Sedikit sekali minat siswa

\section{METODE}

Penelitian ini menggunakan desain penelitian tindakan kelas (PTK), yang merupakan bentuk kajian yang sistematis reflektif, dilakukan oleh pelaku tindakan (guru), dan dilakukan untuk memperbaiki kondisi pembelajaran.

Penelitian dilaksanakan pada siswa Kelas X TKRO-1 SMK Negeri 1 Baureno Kabupaten Bojonegoro Semester Ganjil Tahun Pelajaran 2018/2019 semester 1. Adapun jumlah siswa Kelas X TKRO-1 tersebut adalah 34 siswa. Dengan prosentase kehadiran siswa 93,24\% Penelitian dilakukan pada mata pelajaran Sejarah materi Sejarah dalam konsep ruang dan waktu. Proses pembelajaran yang digunakan selama ini sebagian besar dengan metode ceramah dan tanya jawab. Hal ini menyebabkan keaktifan siswa sangat kurang dan sangat membosankan.

Adapun rencana tindakan ini melalui empat tahap mulai dari (a) perencanaan (planning), (b) tindakan (acting) dan pengamatan (observing), dan (c) refleksi (reflecting).

a. Tahap Pertama : Perencanaan Tindakan

b. Tahap Kedua : Tindakan dan Pengamatan

c. Tahap Ketiga : Refleksi

\section{PEMBAHASAN}

\section{Tahap 1}

\section{Perencanaan}

Dalam perencanaan ini penulis akan mempersiapkan kegiatan pembelajaran dengan langkah-langkah sebagai berikut: dalam mengikuti pelajaran, hal ini dapat terlihat dari keadaan siswa saat menerima pelajaran banyak yang bebicara sendiri, bahkan terkadang mereka diam saja tanpa memperhatikan guru, atau mengerjakan tugas yang ada di pesantren.

1. Menyusun satuan pelajaran yang sesuai dengan paradigma penelitian kelas.

2. Menyusun rancangan tindan dalam bentuk rencana pembelajaran.

3. Menyusun pedoman pengamatan, wawancara dan jurnal.

4. Menyusun rancangan evaluasi program.

\section{Tahap 2}

\section{a. Tindakan}

Kegiatan yang dilaksanakan adalah pembelajaran melalui keterampilan simulasi yang mengharuskan adanya penyelidikan pada materi Sejarah dalam konsep ruang dan waktu yang meliputi; Menjelaskan pengertian perusahaan jasa dan menjelaskan pengertian dan penyajian laporan arus kas. Pada tahap ini dilakukan tindakan yang telah direncanakan, kegiatannya sebagai berikut:

1. Peneliti mengadakan wawancara dengan siswa Kelas X TKRO-1 SMK Negeri 1 Baureno Kabupaten Bojonegoro berkaitan dengan Sejarah dalam konsep ruang dan waktu sebagai tahap awal kegiatan penelitian. Wawancara ini dimaksudkan untuk mengetahui sejauh mana pola-pola yang digunakan oleh siswa Kelas X TKRO-1 SMK Negeri 1 Baureno Kabupaten Bojonegoro melakukan kegiatan membaca serta kelanjutannya dalam proses memahami makna wacana yang dibaca oleh masing-masing siswa.

2. Peneliti menyiapkan lembar tes untuk sejumlah siswa yang akan dijadikan sebagai instrumen penelitian, kemudian membagikan wacana tersebut kepada sejumlah siswa. Penulis memberikan petunjuk-petunjuk kepada seluruh siswa 
agar serempak melakukan pembelajaran yang telah disiapkan dengan tutor sebaya, dengan melakukan cara-cara sebagai berikut:

a. Siswa dikelompokkan menjadi 5 kelompok dimana masing-masing kelompok terdiri dari 7-8 siswa dimana tiap-tiap kelompok akan diberi materi yang berbeda-beda.

b. Siswa membaca materi yang diberikan guru secara seksama dalam kelompo, memahaminya dan mendiskusikan dalam kelompok tersebut.

c. Secara bergantian masing-masing kelompok yang diwakili oleh 2 orang memberikan peenjelasan didepan kelas dengan dibimbing oleh guru.
3. Peneliti menyiapkan dan membagikan lembar soal dan lembar kerja kepada seluruh siswa untuk menjawab pertanyaan berkaitan dengan materi yang telah ditutorkan oleh guru.

4. Peneliti mengumpulkan hasil kerja siswa, kemudian mengoreksi hasil jawaban soal dari semua siswa tersebut untuk memperoleh skor nilai yang dihasilkan.

5. Peneliti mendata hasil nilai yang diperoleh dan menulisnya.

\section{b. Pengamatan}

Lembar observasi yang digunakan dalam mengamati aktifitas Guru telah di isi sesuai dengan observer.

Tabel 1. Lembar observasi aktifitas guru Hasil Pengamatan Guru

\begin{tabular}{|c|c|c|}
\hline No & Unsur Pengamatan & Penilaian \\
\hline 1 & Menyampaikan & 3 \\
\hline 2 & $\begin{array}{l}\text { Pembelajaran } \\
\text { Mengorganisasikan siswa dalam } \\
\text { belajar }\end{array}$ & 4 \\
\hline 3 & Membimbing siswa dalam belajar & 3 \\
\hline 4 & $\begin{array}{l}\text { Menghubungkan dengan materi } \\
\text { sebelumnya }\end{array}$ & 4 \\
\hline \multirow[t]{3}{*}{5} & Memberikan penugasan & 4 \\
\hline & Jumlah & 18 \\
\hline & Rata-rata & 3.6 \\
\hline
\end{tabular}

Keterangan Penilaian

$4=$ Sangat baik

$3=$ Baik

$2=$ Cukup

Hasil observasi terhadap aktifitas guru dalam pelaksanaan pembelajaran menunjukkan bahwa aktifitas guru telah dilaksanakan semua sesuai dengan langkah-langkah pembelajaran melalui media simulasi perolehan skor untuk aktifitas guru adalah 18. Jadi rata-rata penilaian aktifitas guru adalah sebagai berikut:

$$
\begin{aligned}
\text { Rata }- \text { rata } & =\frac{\text { Banyaknya Perolehan Skor }}{\text { Jumlah Point Perkalian }} \\
& =\frac{18}{5} \\
& =3,6
\end{aligned}
$$

Hasil prosentase untuk skor aktifitas guru pada siklus pertama 3,6 dan kegiatan guru pada pertemuan pertama berkategori Baik. Aktifitas siswa dalam hal ini disajikan dalam dua kategori: 


\section{Aktifitas siswa dalam Proses Belajar Mengajar.}

Observasi aktifitas siswa selama proses belajar mengajar dengan metode tutor sebaya tanggal 3 September 2018 observer dengan mengisi lembar yang telah disiapkan meliputi lima indikator aktifitas siswa dalam pembelajaran dengan menggunakan Media Gambar dalam meningkatkan kemampuan pemahaman Materi Sejarah dalam konsep ruang dan waktu. Hasil observasi siswa selama proses belajar menggunakan Media Gambar tanggal 3 September 2018. Diantaranya adalah Aspek Penilaian:

1) Pemahaman materi

2) Kerjasama dalam kelompok

3) Kemampuan menyampaikan materi

4) Hasil evaluasi

Berdasarkan data yang tertuang dalam pengujian tanggal 3 september di atas maka untuk mengetahui gambaran peningkatan prestasi belajar dari pengamatan selama proses pembelajaran siswa Sejarah melalui cara sebagai berikut: Melalui rata-rata prestasi siswa :

$\begin{aligned} M & =\frac{\sum x}{n} \\ M & =\frac{2350}{34} \\ M & =69,12\end{aligned}$

\section{Hasil Persentase Belajar}

Hasil belajar siswa pada siklus I ini dinilai dari hasil evaluasi diakhir siklus berupa tes berbentuk isian di dalam mengerjakan tugas yang sudah disiapkan. Tabel hasil belajar siswa dinilai dari hasil evaluasi pembelajaran setelah menggunakan metode tutor sebaya pada 3 September 2018.

Tabel 2. Hasil Persentase Belajar Siswa Pertemuan Siklus I

\begin{tabular}{lc}
\hline \multicolumn{1}{c}{ Siklus I } & Keterangan \\
Rata-rata & $\mathbf{6 9 , 1 2}$ \\
Persentase & $\mathbf{4 4 , 1 2 \%}$ \\
\hline
\end{tabular}

Rata-rata nilai hasil belajar pada pertemuan pertama $69,12(44,12 \%)$ dan dikategorikan kurang.

\section{Tahap 3}

Refleksi

Selama pembelajaran berlangsung siswa terlihat begitu aktif dan tertarik dengan pelajaran, karena selama pembelajaran Sejarah selalu serius dan menegangkan sehingga siswa tidak begitu aktif dalam belajar. Sejarah dianggap sulit, ternyata dengan pembelajaran melalui keterampilan simulasi, siswa menjadi lebih aktif, senang dengan pelajaran Sejarah dan tidak membosankan. Adapun Hasil Pelaksanaan adalah sebagai berikut:

1) Hasil Observasi Aktivitas Guru Hasil observasi oleh observer, pada siklus I ini aktifitas guru 3,6 dan dikategorikan baik.
2) Hasil Observasi Aktifitas Siswa

- Rata-rata nilai pemahaman siswa adalah 69,12 yang tergolong kurang

- Rata-rata nilai hasil belajar pada pertemuan pertama adalah 69,12 yang tergolong kurang

3) Upaya perbaikan pada siklus II

- Memberikan bimbingan kepada siswa yang masih menghadapi kesulitan dengan jalan membantu menemukan ide atau objek.

- Menggunakan waktu sebaik mungkin.

- Menyajikan kembali beberapa contoh kegiatan Sejarah dalam konsep ruang dan waktu.

\section{Tahap 1 (siklus II)}

Siklus II dilaksanakan selama 2 kali pertemuan yaitu tanggal 17 September 
2018, proses pembelajaran dengan metode simulasi dalam meningkatkan kemampuan pemahaman bentuk-bentuk keputusan bersama. Secara umum gambaran penelitian sebagai berikut:

\section{Perencanaan}

Dalam perencanaan ini peneliti
akan mempersiapkan pembelajaran dengan langkah-langkah sebagai berikut:

1. Menyusun satuan pelajaran yang sesuai dengan paradigma penelitian kelas.

2. Menyusun rancangan tindakan dalam bentuk rencana pembelajaran.

3. Menyusun pedoman pengamatan, wawancara dan jurnal.

4. Menyusun rancangan evaluasi program.

\section{Tahap 2}

\section{a. Tindakan}

Kegiatan yang dilaksanakan adalah pembelajaran melalui keterampilan simulasi yang mengharuskan adanya penyelidikan pada materi Sejarah dalam konsep ruang dan waktu. Pada tahap ini dilakukan tindakan yang telah direncanakan, kegiatannya sebagai berikut: 1 Peneliti mengadakan wawancara dengan siswa Kelas X TKRO-1 SMK Negeri 1 Baureno Kabupaten Bojonegoro berkaitan dengan Sejarah dalam konsep ruang dan waktu sebagai tahap awal kegiatan penelitian. Wawancara ini dimaksudkan untuk mengetahui sejauh mana pola-pola yang digunakan oleh siswa Kelas X TKRO-1 SMK Negeri 1 Baureno Kabupaten Bojonegoro melakukan kegiatan membaca serta kelanjutannya dalam proses memahami makna wacana yang dibaca oleh masing-masing siswa.
2 Peneliti menyiapkan lembar tes untuk sejumlah siswa yang akan dijadikan sebagai instrumen penelitian, kemudian membagikan wacana tersebut kepada sejumlah siswa. Penulis memberikan petunjuk-petunjuk kepada seluruh siswa agar serempak melakukan pembelajaran yang telah disiapkan dengan tutor sebaya, dengan melakukan cara-cara sebagai berikut:

a. Siswa dikelompokkan menjadi 7 kelompok dimana masing-masing kelompok terdiri dari 5-6 siswa dimana tiap-tiap kelompok akan diberikan materi yang berbeda-beda.

b. Siswa membaca materi yang diberikan guru secara seksama dalam kelompok, memahaminya dan mendiskusikan dalam kelompok tersebut.

c. Secara bergantian masing-masing kelompok yang diwakili oleh 2 orang memberikan penjelasan di depan kelas dengan dibimbing oleh guru.

3 Peneliti menyiapkan dan membagikan lembar soal dan lembar kerja kepada seluruh siswa untuk menjawab pertanyaan berkaitan dengan materi yang telah ditutorkan oleh guru.

4 Peneliti mengumpulkan hasil kerja siswa, kemudian mengoreksi hasil jawaban soal dari semua siswa tersebut untuk memperoleh skor nilai yang dihasilkan

5 Peneliti mendata hasil nilai yang diperoleh dan menulisnya.

\section{b. Pengamatan}

Lembar observasi yang digunakan dalam mengamati aktifitas guru telah di isi sesuai dengan observer.

Tabel 3. Lembar Observasi Aktifitas Guru Hasil Pengamatan Guru

\begin{tabular}{clc}
\hline No & \multicolumn{1}{c}{ Unsur Pengamatan } & Penilaian \\
1 & Menyampaikan Tujuan Pembelajaran & 4 \\
2 & Mengorganisasikan siswa dalam belajar & 4 \\
3 & Membimbing siswa dalam belajar & 4 \\
\hline
\end{tabular}




\begin{tabular}{llc}
\hline 4 & Menghubungkan dengan materi sebelumnya & 4 \\
5 & Memberikan penugasan & 4 \\
& Jumlah & 20 \\
& Rata-rata & 4 \\
\hline
\end{tabular}

Keterangan Penilaian

$4=$ Sangat baik

$3=$ Baik

$2=$ Cukup

Hasil observasi terhadap aktifitas guru dalam pelaksanaan pembelajaran menunjukkan bahwa aktifitas guru telah dilaksanakan semua sesuai dengan langkah-langkah pembelajaran melalui media simulasi perolehan skor untuk aktifitas guru adalah 20. Jadi rata-rata penilaian aktifitas guru adalah sebagai berikut:

$$
\begin{aligned}
\text { Rata }- \text { rata } & =\frac{\text { Banyaknya Perolehan Skor }}{\text { Jumlah Point Perkalian }} \\
& =\frac{20}{5} \\
& =4
\end{aligned}
$$

Hasil prosentase untuk skor aktifitas guru pada siklus pertama 4,0 dan kegiatan guru pada pertemuan pertama berkategorikan Sangat Baik.

\section{Aktifitas Siswa}

Observasi aktifitas siswa selama proses belajar mengajar dengan metode tutor sebaya tanggal 17 September 2018 observer dengan mengisi lembar yang telah disiapkan melalui lima indikator aktifitas siswa dalam pembelajaran dengan menggunakan Media Gambar dalam meningkatkan kemampuan pemahaman Materi Sejarah dalam konsep ruang dan waktu. Tabel hasil observasi siswa selama proses belajar menggunakan Media Gambar tanggal 17 September 2018.

Tabel 4. Observasi Aktifitas dan Hasil Evaluasi Siswa Siklus II

\begin{tabular}{llll}
\hline No & \multicolumn{1}{c}{ Nama } & Nilai & Keterangan \\
1 & Abdus Shomad Al Baihaqi & 85 & Tuntas \\
2 & Achmad Zaky Yanuardani & 85 & Tuntas \\
3 & Adi Pramana & 75 & Tuntas \\
4 & Adia Alinata & 80 & Tuntas \\
5 & Aditya Pratama Putra & 65 & Remidi \\
6 & Agung Wahyu Utomo & 75 & Tuntas \\
7 & Agus Ari Wibowo & 75 & Tuntas \\
8 & Agus Irvan Maulana & 90 & Tuntas \\
9 & Ahmad Azus Sony Azhar & 80 & Tuntas \\
10 & Ahmad Hanif Lazuardi & 85 & Tuntas \\
11 & Ahmad Hariyanto & 80 & Tuntas \\
12 & Ahmad Khoironil Wasilata & 80 & Tuntas \\
13 & Ahmad Muzaky Mubarok & 65 & Remidi \\
14 & Ahmad Rizal Avriyansyah & 80 & Tuntas \\
15 & Ahmad Saddam Nur Abidin & 85 & Tuntas \\
16 & Ahmad Wahib & 90 & Tuntas \\
17 & Ahmad Zakki Maysunun & 80 & Tuntas \\
18 & Ahmad Zamroni Sulaiman & 70 & Remidi \\
19 & Ahmad Zarkhoni & 75 & Tuntas \\
20 & Akbarrul Mufti & 80 & Tuntas \\
21 & Aldo Prima Eka Wijaya & 75 & Tuntas \\
22 & Alfian Andre Susanto & 70 & Remidi \\
23 & Alif Nor Irfansah & 75 & Tuntas \\
\hline
\end{tabular}




\begin{tabular}{llll}
\hline 24 & Andre Eko Saputro & 75 & Tuntas \\
25 & Anggardi Fajar Agustian & 90 & Tuntas \\
26 & Ardiansyah Nur Ramadhan & 75 & Tuntas \\
27 & Arifqi Roziqul Akbar & 75 & Tuntas \\
28 & Arya Dharma Wijaya & 75 & Tuntas \\
29 & Avid Budi Kurniawan & 90 & Tuntas \\
30 & Bagas Mahendra & 85 & Tuntas \\
31 & Bagus Rizky Saputra & 75 & Tuntas \\
32 & Bintang Rokhi Ahmad Firdaus & 65 & Remidi \\
33 & Chaidir Alfa Mubarok & 80 & Tuntas \\
34 & Daniel Rizkia Purnama & 85 & Tuntas \\
& Jumlah & $\mathbf{2 6 7 0}$ & $\mathbf{2 9}$ \\
& Rata-rata & $\mathbf{7 8 , 5 3}$ & $\mathbf{8 5 , 2 9 \%}$ \\
\hline
\end{tabular}

Aspek Penilaian

1) Pemahaman materi

2) Kerjasama dalam kelompok

3) Kemampuan menyampaikan materi

4) Hasil evaluasi

Berdasarkan data yang tertuang dalam tabel di atas maka untuk mengetahui gambaran peningkatan prestasi belajar dari pengamatan selama proses pembelajaran siswa Sejarah malalui cara sebagai berikut:

Melalui rata-rata prestasi siswa:

$\begin{aligned} M & =\frac{\sum x}{n} \\ M & =\frac{2670}{34} \\ M & =78,53\end{aligned}$$$
\begin{aligned}
M & =\frac{2670}{34} \\
M & =78,53
\end{aligned}
$$

\section{Hasil Persentase Belajar}

Hasil belajar siswa pada siklus I ini dimulai dari hasil evaluasi diakhir siklus berupa tes berbentuk isian di dalam mengerjakan tugas yang sudah disiapkan. Tabel hasil belajar siswa dinilai dari hasil evalusai pembelajaran setelah menggunakan metode tutro sebaya pada 17 September 2018.

Tabel 5. Hasil persentasi belajar siswa pertemuan siklus II

\begin{tabular}{cc}
\hline Siklus I & Keterangan \\
Rata-rata & $\mathbf{7 8 , 5 3}$ \\
Persentase & $\mathbf{8 5 , 2 9 \%}$ \\
\hline
\end{tabular}

Rata-rata nilai hasil belajar pada pertemuan kedua adalah $\mathbf{7 8 , 5 3}(\mathbf{8 5 , 2 9 \%})$ dan dikategorikan baik.

\section{Tahap 3}

\section{Refleksi}

Adapun Hasil Pelaksanaan Aktivitas Guru

1) Hasil Observasi Aktivitas Guru Hasil observasi oleh observer, pada siklus I ini aktifitas guru 4,0 dan dikategorikan sangat baik.

2) Hasil Observasi Aktifitas Siswa

- Rata-rata nilai pemahaman siswa adalah 78,53 yang tergolong baik.
- Rata-rata nilai hasil belajar pada pertemuan pertama adalah 78,53 yang tergolong baik.

3) Dari hasil penelitian dapat diketahui bahwa dengan upaya yang maksimal dilakukan oleh guru hasil yang didapat seperti tersebut, maka penelitian dicukupkan pada siklus ke II.

\section{Hasil Siklus I}

a. Rata-rata penilaian proses pembelajaran siswa adalah 69,12. 
b. Rata-rata hasil belajar siswa adalah

\section{9,12.}

\section{Hasil Siklus II}

a. Rata-rata penilaian proses pembelajaran siswa adalah 78,53

b. Rata-rata hasil belajar siswa adalah $\mathbf{7 8 , 5 3}$
Berdasarkan hasil observasi aktivitas siswa yang didasarkan aspek mengerti, berpikir, pandangan, tahu benar, pandai dalam proses pembelajaran serta dilihat dari hasil evaluasi diakhir setiap siklus dapat dinyatakan mengalami peningkatan.

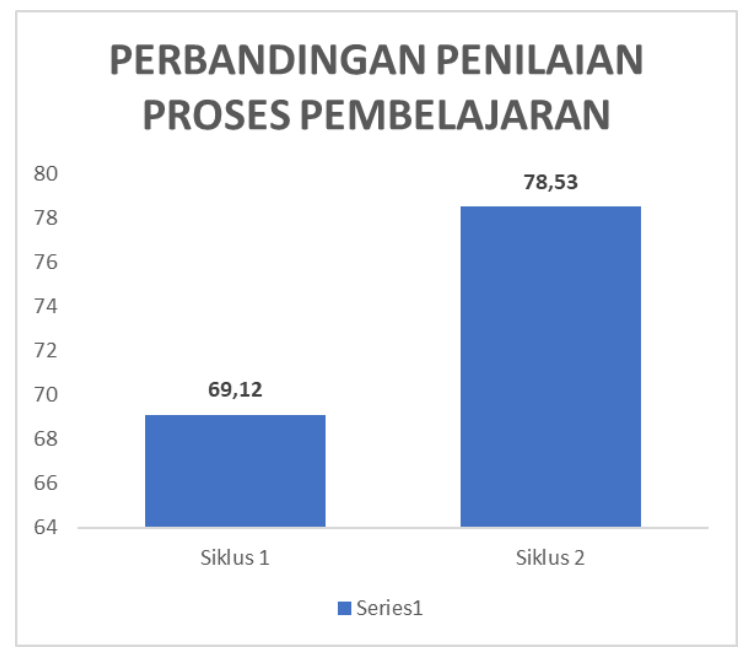

Gambar 1. Perbandingan Penilaian Proses Pembelajaran

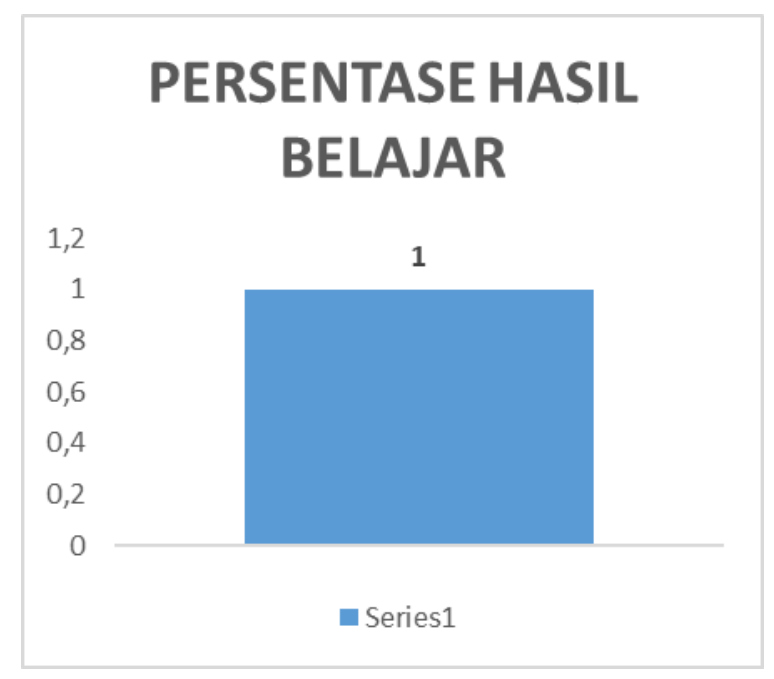

Gambar 2. Perbandingan Persentase Hasil Belajar

\section{KESIMPULAN}

Dengan memperhatikan hasil pada penelitian tindakan kelas ini serta mengacu pada rumusan masalah maka peneliti dapat menarik kesimpulan bahwa penggunaan teknik tutor sebaya dalam pembelajaran Materi Sejarah dalam konsep ruang dan waktu yang dilakukan di 
Kelas X TKRO-1 SMK Negeri 1 Baureno Kabupaten Bojonegoro Semester Ganjil Tahun Pelajaran 2018/2019 adalah sebagai berikut metode tutor sebaya dapat meningkatkan prestasi siswa pada mata pelajaran Sejarah siswa SMK Negeri 1

\section{DAFTAR PUSTAKA}

Baharudin, Esa Nur Wahyuni, 2007. Teori Belajar dan Pembelajaran. Jogjakarta: Ar-ruzz media.

Depdiknas, 2003. Garis-garis Besar Program Pengajaran Mata Pelajaran. Jakarta: Depdikbud.

-------------, 2006. Lampiran Peraturan Menteri Pendidikan Nasional No. 22 tahun 2006 tanggal $23 \mathrm{Mei} 2006$ (Perment 22-23, 2006)

Lie. Anita 2002. Cooperative Learning. Mempraktikkan Cooperative Learning
Baureno Kelas X TKRO-1, terbukti dengan meningkatnya nilai rata-rata hasil belajar dari dua siklus berikut : siklus I $(69,12)$ persentase $44,12 \%$, siklus II $(78,53) 85,29 \%$.

di ruang-ruang kelas. Jakarta: Gramedia Widiasarana

Purwanto Ngalim 1991. Prinsip-prinsip dan Teknik Evaluasi Pengajaran. Bandung : Rosdakarya

Sudjana N. dan Ibrahim 1989. Penelitian dan Penilaian Pendidikan. Bandung Sinar Baru

Syaiful Bahri Djamarah, 1991. Prestasi belajar dan kompetensi guru. op. Cit

Surakhmad, Winarno. 1982. Pengantar penelitian Ilmiah. Dasar Metodik Teknik. Bandung: Tarsito 